\title{
Commercial Public Service Broadcasting in the United Kingdom: Public Service Television, Regulation, and the Market
}

Ramsey, P. (2017). Commercial Public Service Broadcasting in the United Kingdom: Public Service Television, Regulation, and the Market. Television and New Media, 18(7), 639-654. [18(7)].

https://doi.org/10.1177/1527476416677113

Link to publication record in Ulster University Research Portal

\section{Published in:}

Television and New Media

Publication Status:

Published (in print/issue): 01/11/2017

DOI:

$10.1177 / 1527476416677113$

\section{Document Version}

Author Accepted version

\section{General rights}

Copyright for the publications made accessible via Ulster University's Research Portal is retained by the author(s) and / or other copyright owners and it is a condition of accessing these publications that users recognise and abide by the legal requirements associated with these rights.

\section{Take down policy}

The Research Portal is Ulster University's institutional repository that provides access to Ulster's research outputs. Every effort has been made to ensure that content in the Research Portal does not infringe any person's rights, or applicable UK laws. If you discover content in the Research Portal that you believe breaches copyright or violates any law, please contact pure-support@ulster.ac.uk. 
Commercial Public Service Broadcasting in the United Kingdom: Public Service

Television, Regulation, and the Market

Phil Ramsey, Ulster University

pt.ramsey@ulster.ac.uk

http://ulster.academia.edu/PhilRamsey | http://orcid.org/0000-0001-5873-489X

\title{
Published as:
}

Ramsey, P. (2016). Commercial Public Service Broadcasting in the United Kingdom: Public Service Television, Regulation, and the Market. Television \& New Media.

(http://dx.doi.org/10.1177/1527476416677113)

\begin{abstract}
The commercial public service broadcasters (PSBs) in the United Kingdom (UK) make a significant contribution to the country's public service television system, alongside the BBC. Operating under the UK communications regulator Ofcom, the commercial PSB channels ITV, Channel 4 , and Channel 5 are required to broadcast varying levels of public service content. This places these channels in a different category to all other market broadcasters in the UK. By taking a critical political economy of communication approach, this article examines how the regulatory system functions to secure public service provision in television. A particular focus is placed on the first-run originations quotas, which govern the levels of programming that are originally produced or commissioned by a commercial PSB, and broadcast for the first time in the UK. It is argued that while fulfilling the public service remit, the commercial PSBs gain significant benefits that contribute to the underpinning of their business models.
\end{abstract}

Keywords: public service television, Ofcom, media regulation, media policy, political economy of communication, commercial public service broadcasting 
Commercial Public Service Broadcasting in the United Kingdom: Public Service Television, Regulation, and the Market

\section{Introduction}

While the BBC is the United Kingdom's (UK) main public service broadcaster (PSB), the UK's commercial PSBs make an important contribution to the overall framework of the public service television system. In return, they receive considerable benefits which they gain from being part of the PSB framework, that contributes directly to underpinning their business models. A critical political economy of communication approach is taken in this article to the UK's commercial PSBs, a group made up of the television channels ITV, Channel 4 and Channel 5. Resulting from the analysis it is argued that the framework that the commercial PSBs operate within ought to be conceptualised in a way that highlights the distinction between it and that framework which their non-PSB counterparts operate within. In other words, the short-hand distinction (commonly used journalistically) between the BBC and the other 'marketbased' broadcasters which posits them respectively 'public'/'private' is a clumsy one, and means that the importance of the current governance system and its maintenance can be missed. It is argued in this article that there is a dearth of attention given to the contribution made by the commercial PSBs to a plural and democratic media system; this is shown to be stark in contrast to the limited contribution made by the non-PSB organisations, a group which broadcasts all other UK television channels.

A focus is placed in this article on the quotas in relation to 'first-run originations' that the commercial PSBs are required to fulfil: that is programming which is originally produced or commissioned by a UK broadcaster, and shown for the first time within the country. This regulatory framework which delivers high spending on originations outside of sports programming is compared to that of the non-PSB television sector, where a very large proportion of money spent in this category is on sport. The first-run originations category is one key area where the PSB regulatory framework functions to ensure a form of broadcasting which meets the PSB requirements discussed below. The framework also helps demarcate a PSB system which remains normatively important within the wider broadcasting market. It is argued that the public service television system that is administered by the UK 
communications regulator Ofcom may come under political pressure to be further liberalised.

\section{Applying Critical Political Economy of Communication to Public Service Broadcasting}

Critical political economy of communication is a well-developed field within media and communication research, strongly influenced by the British tradition, shaped by the work of Murdock and Golding (see Golding and Murdock 2000; Murdock and Golding 1997), and Garnham (1979, 2010), among others, If the approach is less popular within media and communication studies than the more dominant cultural studies approaches, it does have strong communities of scholars working in North America, (eg. McChesney 2013; Mosco 2009), Western Europe (eg. Hardy 2014) and, for example, Australasia (eg. Thompson 2011). Mosco (2009, 2) defines political economy as "the study of the social relations, particularly the power relations, that mutually constitute the production, distribution, and consumption of resources, including communication resources". Here a focus is placed on flows of capital and labour, and on ownership and power in the media and communications industries. In addition, critical political economy of media and communication often encompasses a critical historical approach, as shown in the propensity of its proponents to illustrate the historical context of contemporary research subjects, and for the way in which the flexibility of the methods and disciplines it draws upon allows for this (eg. sociology). Moreover, the history of communication itself is one area subject to critical political economy accounts (see Mosco 2009, 109-113).

For Hardy, the critical political economy of communication approach "rests on a central claim: different ways of organizing and financing communications have implications for the range and nature of media content, and the ways in which this is consumed and used" (Hardy 2014, 7). According to Potschka (2012, 26), this form of analysis:

provides an appropriate framework to investigate the shift from state control to market hegemony... it incorporates the relationship between transitions in the 
media and macroeconomics as well as socio-cultural paradigm changes and recognizes the special nature of the media and its societal and democratic function.

Potschka's argument here is directly applicable to the present study, as the commercial PSBs are required to contribute to broadcasting which conforms to such a special nature in the UK's television system despite operating under market conditions. Here the critical political economy of communication approach provides a frame whereby the role of the commercial PSBs can be assessed and judged for its normative value.

A critical political economy approach to PSB can encompass both publicly funded and commercial public broadcasting, an approach exemplified in some of the research carried out in this area. Golding and Murdock $(2000,75)$ use the BBC as an example of an "institutional counter to the commodification of communicative activity". Later Murdock notes that in relation to the BBC's commercial activities, "By introducing calculations around the potential for commodification into institutional strategies ... they compromise the moral economy of public goods" (Murdock 2010, 35). Addressing ITV, which is the main commercial PSB in the UK, Hardy $(2012,106)$ notes that the broadcaster has "lobbied, with success, for its PSB obligations to be reduced as it managed declining advertising revenues and audiences, and the diminishing value of its analogue spectrum". (Later we return to ITV as a company which reaps significant benefits from its role as the main commercial PSB.) Finally, Born $(2003,792)$ found in her analysis of Channel 4 that the "assumption seems to be that C4's commercial activities can have no detrimental effect on its PSB commitments; but even in purely economic terms such a view cannot be sustained".

\section{The BBC as a methodological case-study}

While the $\mathrm{BBC}$ is not intended as the main focus of this article, we can use the Corporation as an example for this form of political-economy analysis. As is the case throughout this article, qualitative document analysis (Atkinson and Coffey 2004; Forster 1994; Mason 2002) is used as a means of generating a range of data, such as information on legislation and regulation and on the finances of the broadcasters 
considered here. A range of reports, documentation and resources accessed through institutional and company websites have been considered from institutions including: the BBC; the BBC Trust; Ofcom; ITV plc; Channel Four Television Corporation (C4C) and Channel 5. In each case where the article discusses contemporary conditions the most relevant and recent documents are used, which in some cases means drawing on data which might not have been updated for two/three years (1).

While the BBC's income comes predominantly from the television licence fee, a form of public funding, its income is supplemented by activities within the private sector, both in the UK and globally. As the Corporation's licence fee income continues to shrink - in the context of government imposed freezes to the licence fee and additional funding responsibilities placed upon the $\mathrm{BBC}$ - the impetus for the $\mathrm{BBC}$ to raise its revenues from these sources makes pertinent the importance of analysis and greater transparency on the BBC's commercial activities (see Hewlett 2015). Drawing our attention now to these activities, BBC Worldwide (the commercial arm of the BBC) had sales of over $£ 1.002 \mathrm{bn}$ in 2014-15 earned nationally and globally in the marketplace (BBC 2015, 134). This entailed a largemarket based return to the licence fee-funded BBC television channels of $£ 226.5$ million in 2014-15 (BBC 2015, 131). Such a return means that critical analysis of the $\mathrm{BBC}$ must take account of market activities that fall outside of the licence fee, where there has been a death of analysis up to this point (with some exceptions, eg. Donders and Van den Bulck, 2016). Indeed, as BBC Worldwide is now itself a significant commissioner of content - £94 million in 2014-15 (BBC 2015, 135) - the performance of it directly impinges on that content which is carried on the licence-fee funded channels. Rather than the BBC's commercial activities being conceptualised and analysed separately to that research which focuses on the licence-fee funded Corporation, BBC Worldwide should instead be considered alongside the rest of the Corporation.

In addition to addressing the structural conditions of the $\mathrm{BBC}$, it follows that attention to individual remuneration of directors at the Corporation should also come under scrutiny: for example, Tim Davie the CEO of BBC Worldwide \& Director, Global, was due to receive a salary of $£ 400,000$ in $2015-16$, not including a bonus option. This salary "is funded entirely by the BBC's commercial operations and is not paid for or subsidised by the licence fee" (BBC 2015, 112), and the suggestion is that it should be uncontroversial to the critics of high-pay at the BBC (in the way that, say, 
the salaries of the CEOs of ITV plc and C4C are). And yet, as a member of the Executive Board of the BBC (and as of July 2015 the Corporation's second-highest paid employee after the Director-General Tony Hall who earns £450,000), Davie ought not to escape scrutiny. Rather his role, and his performance, are both directly affected by and in turn effect the licence-fee funded part of the BBC.

\section{The UK television market}

The UK television industry had a revenue of $£ 13.2 \mathrm{bn}$ in 2014,21 per cent of which originated from public funding (Ofcom 2015a, 145). By far the largest share of revenue is from subscription services, contributing $£ 5.9 \mathrm{bn}$, far ahead of the $£ 3.8 \mathrm{bn}$ that came from advertising (Ofcom 2015a, 165). Of this, the share of advertising is mainly dominated by ITV/STV/UTV and ITV Breakfast which gained 35 per cent, and the multi-channel sector which gained 27 per cent (Channel 4: 12 per cent; Channel 5: 7 per cent; PSB portfolio channels: 17 per cent) (Derived from Ofcom 2015a, 148). These significant revenue shares are driven largely by the high audience shares that the five main PSB channels command in the multi-channel era. In 2014, 51.2 per cent of all viewing was to BBC One, BBC Two, ITV, Channel 4 and Channel 5. While this has been in overall and steep decline since the early 1990s, Ofcom has noted that it stabilised for the first time between 2013-2014 (Ofcom 2015a, 192). Whether that is a harbinger of future stability remains to be seen. However, it is these five main PSB channels (of which three are commercial PSBs) that remain overwhelmingly popular with the audience. For example, when sport is excluded, Ofcom found that the twenty television programmes in the UK with the highest audiences in 2014 were all shown on either BBC One (thirteen) or ITV (seven) (Ofcom 2015a, 161).

\section{The Role of Ofcom}

As the UK's communications regulator, Ofcom has a range of regulatory functions that mostly stem from the Communications Act 2003, which has been called "a sweeping programme of regulatory change ... the most comprehensive legislation of 
its kind in British history" (Doyle and Vick 2005, 76). Under the terms of the Act, Ofcom was charged with carrying periodical reviews of the PSB system, the most recent of which was published as Public Service Broadcasting in the Internet Age (Ofcom 2015b), and is charged with conducting on-going reviews of PSB in the UK (Ofcom 2015c). Ofcom has its own set of 'PSB purposes and characteristics' (Ofcom 2015c, 4-5), with Ofcom summarising the purposes of PSB as being: "to deal with a wide range of subjects; to cater for the widest possible range of audiences - across different times of day and through different types of programme; and to maintain high standards of programme-making" (Ofcom 2015c, 4). One of the PSB characteristics is that content should be 'Original', with the principle being that the PSB channels in part broadcast "New UK content rather than repeats or acquisitions" (Ofcom 2015c, 5), which directly pertains to the discussion below about the role of the first-run originations quotas. These quotas do not relate to the content of programming, but rather ensure that it is original, and thus all forms of programming may be encompassed within it. That said, the PSB purposes and characteristics do ensure that across the board the commercial PSBs are contributing to the delivery of a public television system that stands apart from the non-PSB sector.

\section{The UK's commercial PSBs}

The UK's commercial PSBs channels are ITV (previously known as 'ITV1'), Channel 4, Channel 5 and S4C, channels which along with the BBC's television channels form the UK's public service television system. The category of non-PSB channels is comprised of every other channel broadcast on UK television lying outside of this group (2). The funding models and ownership structures of the broadcasters who run these channels differ. ITV is a UK PLC and thus shareholder owned. Channel 5 is owned by the US global-national Viacom Inc, which was bought by the company from Northern \& Shell in September 2014 for $£ 450$ million (Viacom 2014). Third, Channel 4 is broadcast by $\mathrm{C} 4 \mathrm{C}$, a publicly owned, statutory corporation, which is mainly commercially funded through advertising. While $\mathrm{C} 4 \mathrm{C}$ is alike to the $\mathrm{BBC}$ in the sense that it is publicly rather than privately owned, it does not receive any licence fee 
income. Its main broadcast operation Channel 4 does, however, have a more stringent public service remit than ITV and Channel 5 (discussed below).

$\mathrm{S} 4 \mathrm{C}$, the Welsh-Language broadcaster, is mostly funded from the licence fee and direct grant, though some 2 per cent of its income comes through commercial sources including advertising (S4C 2015). Given this small proportion, S4C is not generally considered alongside the other commercial PSBs in the data that stems from Ofcom, and is accordingly not considered in this article on a full-footing with the other commercial PSBs. In the case of ITV, Channel 4 and Channel 5, these are channels are part of larger media organisations, with additional television channels and online provision (3). These channels are augmented by time-shifted reruns on other channels.

In order to achieve the characteristics of public service television that it seeks, the Communications Act 2003 allows for separate public service remits for ITV (ie. the ITV licences and STV), Channel 4 and Channel 5. In the case of ITV and Channel 5, "The public service remit ... is the provision of a range of high quality and diverse programming" (Communications Act 2003, 265.2). Channel 4, distinct from Channels 3 and 5 in its ownership status as previously discussed, is set a more detailed and precise remit. Like 3 and 5 it must produce high quality and diverse programming, but in addition, it must produce programming which for example "demonstrates innovation, experiment and creativity in the form and content of programmes" (Communications Act 2003, 265.3). The Digital Economy Act 2010 later made additional provisions for Channel 4's remit. Finally, while the PSBs are governed by the regulations discussed, among others, the non-PSB channels are not free from all regulation: for example, they are required to adhere to Ofcom's Broadcasting Code (Ofcom 2013a) which governs areas such as harm and offence and applies to all television channels broadcast in the UK.

\section{The UK first-run originations quotas}

Ofcom has the power under the Communications Act 2003 to regulate the commercial PSBs on programming quotas for first-run originations, which are: "Programmes commissioned by or for a licensed public service channel with a view to their first showing on television in the United Kingdom in the reference year" (Ofcom 2015d, 
413). These are distinct in the Ofcom terminology from first-run acquisitions, those programmes which are bought-in by a broadcaster and shown on UK television for the first time. These quotas are one way in which the programming of the commercial PSBs is demarcated from programming from the non-PSBs (see table 1), and which allow Ofcom to regulate for the PSB characteristic on 'original' programming discussed above (Ofcom 2015c, 5).

Table 1. Originally produced or commissioned quotas for ITV, Channel 4 and Channel 5: 2004 and 2013

\begin{tabular}{|c|c|c|}
\hline Channel & (Original) 2004 Quotas & 2013 Quotas \\
\hline $\begin{array}{l}\text { ITV (London } \\
\text { ITV)* }\end{array}$ & $\begin{array}{l}65 \% \text { 'originally produced or } \\
\text { commissioned'; } 85 \% \text { during peak } \\
\text { time hours }\end{array}$ & $\begin{array}{l}65 \% \text { 'originally produced or } \\
\text { commissioned'; } 85 \% \text { during peak } \\
\text { time hours }\end{array}$ \\
\hline Cha & $\begin{array}{l}60 \% \text { 'originally produced or } \\
\text { commissioned'; } 70 \% \text { during peak } \\
\text { time hours }\end{array}$ & $\begin{array}{l}56 \% \text { 'originally produced or } \\
\text { commissioned'; } 70 \% \text { during peak } \\
\text { time hours }\end{array}$ \\
\hline Cha & $\begin{array}{l}51 \% \text { 'originally produced or } \\
\text { commissioned'; } 42 \% \text { during peak } \\
\text { time hours }\end{array}$ & $\begin{array}{l}50 \% \text { 'originally produced } \text { or } \\
\text { commissioned'; } 40 \% \text { during peak } \\
\text { time hours }\end{array}$ \\
\hline
\end{tabular}

* London ITV is used here as an example, as each ITV region has an individual licence Sources: Ofcom 2004, 2013b.

From the Ofcom data considered in this study, there are two main points to be made (given the time-lag in the release of statistics, the data considered here was the most current when this research was being conducted). First, the $\mathrm{BBC}$ channels and the other main commercial PSBs spent $£ 2.45$ bn on first-run UK originations in 2013 (see table 2); the non-PSB channels spent $£ 1.96$ bn on first-run UK originations in the same year. However, spending by the PSBs in this category was only at 1998 levels, with spending reaching a peak in 2004 at $£ 3.3$ bn (Ofcom 2015d, 2). By contrast, the nonPSB channel's spending has been steadily rising, from $£ 1.38 \mathrm{bn}$ in 2008 to $£ 1.96 \mathrm{bn}$ in 2013 (Ofcom 2015d, 3). When sport is examined within the figures, the contrast between the PSB and non-PSB channels is stark. While sport dominates this figure for the non-PSBs, only 16.29 per cent of PSB spending in this category is on sports (see table 2). 
Table 2. Broadcaster spending on first-run UK originations (2013)

\begin{tabular}{|l|c|c|c|}
\hline Broadcaster & Spending & $\begin{array}{c}\text { Percentage Spent on } \\
\text { Sport }\end{array}$ & $\begin{array}{c}\text { Percentage } \\
\text { Spent on other } \\
\text { genres }\end{array}$ \\
\hline All PSBs & $£ 2.45 \mathrm{bn}$ & $16.29 \%$ & $83.71 \%$ \\
\hline $\begin{array}{l}\text { Commercial PSBs } \\
\text { (excluding BBC) }\end{array}$ & $£ 1.24 \mathrm{bn}$ & $\approx 16.49 \%$ & $\approx 83.51 \%$ \\
\hline Non-PSBs & $£ 1.96 \mathrm{bn}$ & $82.14 \%$ & $17.86 \%$ \\
\hline
\end{tabular}

Source (data derived from or based on): Ofcom 2015d, 2-5.

The figure for the commercial PSBs (excluding the BBC) cannot be ascertained precisely, as it is not known exactly what percentage of the BBC's spend goes on sport (due to, among other reasons, spending on sport being divided across multiple services). The projected figure for the money spent on sport by the commercial PSBs of 16.49 per cent has been calculated by taking into consideration that they spend 50.6 per cent of the total spend on first run originations of $£ 2.45 \mathrm{bn}$ (the BBC spending 49.4 per cent) (Ofcom 2015c, 2). This is then reassigned to the percentage of the approximate the figure spent on sport by the all the PSBs (share of $£ 399 \mathrm{~m}$ ) (Ofcom 2015d, 5). While this calculation may be considered something of a crude tool, consideration of various factors tends to suggest that it could be a workable approximation. Contained in a report (BBC Trust/MTM London 2011, 7) is the rare publication of the figure of $£ 261 \mathrm{~m}$ that the BBC spent on sports rights in 2009-10 (such figures are not normally released). Given that the BBC's sports rights budget was cut by 15 per cent under the Delivering Quality First cuts of 2011 (BBC Trust 2011, 9), this would mean that the BBC's spend on sport has become more modest than it was previously (5).

Second, when comparing the non-PSBs to the commercial PSBs, the 17.86 per cent that the non-PSBs spend on first-run originations in programme genres other than sport is paltry in comparison to the projected 83.51 per cent spent by the commercial PSBs on other programme genres. Given that the non-PSBs are collectively comprised of hundreds of channels the some $£ 350 \mathrm{~m}$ that the non-PSBs spend is dwarfed by the $\approx £ 1.03$ bn for the commercial PSBs (83.51 per cent of $£ 1.24 \mathrm{bn}$, table 2). That said, spending in this category is "up $43 \%$ in real terms from $£ 245 \mathrm{~m}$ in 2008 " (Ofcom 2015d, 3). Spending on sport by the non-PSBs has been fuelled mainly by the (English) Premier League soccer rights acquisitions, with the traditional subscription 
TV provider Sky facing massive competition from the comparatively new-entrant BT. The latest deal that involved BT and Sky paying $£ 5.1 \mathrm{bn}$ runs for three seasons from 2016-2019 (Ofcom 2015a, 183). When BT's additional purchase of rights for the UEFA Champions League and Europa League are added in, this amounts to $£ 2.01 \mathrm{bn}$ "a year on the rights to live coverage from these competitions alone" (Ofcom 2015a, 183).

\section{Original programming and the public service imperative}

The first-run UK originations quotas ensure that the market makes a significant contribution to delivering the public service remit within the UK media system. Harnessing such the public service provision of the commercial PSBs contributes to a much greater plurality in public service provision than would be the case if only the $\mathrm{BBC}$ had a public service remit. As has been outlined, the commercial PSBs make up more than half of the spending on first-run originations by the PSBs overall. Without the commercial PSBs being held to these regulations the public service television system would be greatly diminished. But what, in essence is the 'public service' value of original programming, or in other words, should the PSB characteristic of originality (in the Ofcom sense) be considered something which serves the public interest?

Ensuring that the audience has access to original programming, intended for first broadcast in the UK, ensures that it stands apart from programming laden with imported content (often mainly sourced from the USA), or repeats of previously broadcast content. As has been evidenced here, there is a substantial difference in the extent to which the commercial PSBs deliver original programming as compared with the non-PSBs which are not required to meet quotas in this category. While the characteristic that the first-run originations quotas are designed to deliver on is not on its own enough to solely demarcate public service television from the rest of the market, it does make a substantial contribution to doing so. However, harnessing the market to make its contribution to the public service television system can also be mutually-beneficial to the commercial PSBs. We now turn to a consideration of these benefits and of how they contribute directly to underpinning the business models of the commercial PSBs. 


\section{Benefits from the Public Service Remit}

While we have discussed up to this point how Ofcom regulation requires the commercial PSBs to comply with particular quotas, the critical political economy approach to the commercial PSBs also allows for greater attention to be paid to the benefits that the public service remit can bring to these broadcasters. Here the main benefits are described as "predominantly access to spectrum (the valuable radiowaves that support wireless communication) to broadcast their services; prominence on electronic programme guides on television" (Ofcom 2015b, 1). Ofcom (2015b, 28) notes that "Appropriate prominence continues to be one of the few key sources of regulatory benefit to PSB providers. We believe that in an increasingly complicated and fragmented digital world, the importance of these principles grows". However, this statement appears to play down the importance of EPG prominence - especially the phrase "one of the few" - a benefit which when the financial positions of the broadcasters are considered (see table 3 ) seems to be extremely important, especially in the case of ITV.

Prominence is both historically and contemporaneously what the business model of a broadcasting company such as ITV is built upon. For example, during its financial year in 2014, ITV plc reported revenue of $£ 2.6 \mathrm{bn}$, and adjusted profit before tax of $£ 712 \mathrm{~m}$ (a 559 per cent increase since 2009) (ITV 2014, 5). Its operating profit of $£ 651 \mathrm{~m}$ in 2014 was a 61.1 per cent rise on 2010. At the cornerstone of these earnings are the company’s broadcast and online operations which contributed over $£ 2.02 \mathrm{bn}$ to revenue (ITV 2014, 6). As the main ITV channel is a major contributor to this, we can posit that the company's sole channel with a public service remit is the anchor of its earnings. While this is somewhat speculative - the profitability of the individual channels is not reported - there is evidence reported by Ofcom which tends to back up this assertion. In 2014, the advertising share of the total television market gained by ITV/STV/UTV/ITV Breakfast was $£ 1.37 \mathrm{bn}$, which dwarfs the $£ 0.65$ bn gained by the PSB portfolio channels collectively (Ofcom 2015a, 148). 
Table 3. Operating profits (ITV plc/Channel 5) / Operating surplus (C4C) of UK commercial PSBs in millions

\begin{tabular}{|l|l|l|l|l|}
\hline Company & $\mathbf{2 0 1 1}$ & $\mathbf{2 0 1 2}$ & $\mathbf{2 0 1 3}$ & $\mathbf{2 0 1 4}$ \\
\hline ITV plc & $£ 404.0$ & $£ 453.0$ & $£ 546.0$ & $£ 651.0$ \\
\hline $\begin{array}{l}\text { Channel Four } \\
\text { Television } \\
\text { Corporation } \\
\text { (C4C) }\end{array}$ & $£ 41.0$ & $(£ 29.0)$ & $(£ 15.0)$ & $£ 4.0$ \\
\hline $\begin{array}{l}\text { Channel 5 } \\
\text { (Northern \& } \\
\text { Shell) }\end{array}$ & $£ 26.2$ & $(£ 16.6)$ & $£ 32.6$ & $\mathrm{~N} / \mathrm{A}^{4}$ \\
\hline
\end{tabular}

Sources: $\quad$ Channel 4 2014, 168; Farey-Jones 2012; ITV 2012, 96; ITV 2014, 107; Northern \& Shell 2013, 3.

Indeed, implicit in ITV's business model is that the investment in the ITV 'brand' stems from the main ITV channel: this is described by the company as a form of progression, with one step leading to the next: "Building our ITV television and main channel brand; Extending that brand to our portfolio of channels and digital assets to reach all demographics; Growing our portfolio of programme brands and extending those brands beyond the television set" (ITV 2014, 8). Indeed, while only the main ITV channel has PSB regulatory responsibilities to fulfil, it is this channel that drives brand recognition in its portfolio of channels, gives it a prominent role as a provider of news, and which gives maximum exposure to major television shows (such as The $X$ Factor), from which its spinoff shows can be broadcast on its other channels.

The three commercially-funded PSBs were mostly profit making in the years 20112014 - or in the case of ITV plc, very profitable (table 3) - while delivering their first-run originations quotas. As we have seen, the impact of the first-run originations quotas ensure that these broadcasters generate large amount of original programming, which can be rerun or developed through spin-off programmes through the portfolio channels of these broadcasters. As UK audience demand is still largely for UKoriginated television, the quotas ensure that these commercial PSBs are replete with content - content which must compete on quality with the BBC, in the PSB system which can then be sold to international markets, often attracting high returns (eg. as in the case of Downton Abbey).

Despite the mass-proliferation of television channels in the multi-channel era, none of these come close to matching the audience share of the three commercial PSBs. For 
example, the entire Sky portfolio of channels only had an 8.2 per cent audience share in 2014, a decline from 10.6 per cent in 2004 (Ofcom 2015a, 202). Thus EPG prominence, alongside the demand for UK originated content, consolidates the place of the commercial PSBs in the multi-channel media system. If it can be described as "one of the few key sources of regulatory benefit to PSB providers" (Ofcom 2015b, $28)$, it is at the very least an exceptionally important one.

Even if the importance of EPG prominence becomes eroded over time, through the growing importance of online streaming for example, the commercial PSBs have had their place historically secured at the centre of the media system. In terms of 'brand recognition', their place at the forefront of television before the multi-channel era on satellite and cable (and in the case of Channel 5 before mass proliferation of multichannel choice through DTT) has been secured. While these benefits can be relatively hard to quantify in some areas, the legacies of these businesses in terms of capital accumulation and profitability are central to their current positions (eg. Viacom's purchase of Channel 5 led to a large windfall for Northern \& Shell, stemming from a business built on PSB prominence).

\section{Future policy challenges for public service television}

The events leading up to the publication of the White Paper on the BBC (Department for Culture, Media and Sport 2016) - the government paper which sets out the basis of what the BBC's next Royal Charter will include - rightly placed the BBC at the centre of public and political debate regarding public service television. However, the debate is too often divorced from a wider conversation on how the public service television system should be planned and implemented, and often discounts the vital role played by the commercial PSBs. While Ofcom suggests that the BBC is "the cornerstone of the PSB system and is the key driver of investment across the system" (Ofcom 2015a, 3), it is a system that depends greatly on ITV, Channel 4 and Channel 5. The current PSB regulatory system ought not be taken for granted by scholars and policy analysts, especially given that a new Communications Bill may be introduced at some point in the close-term in the UK political cycle. With a majority Conservative government elected in May 2015, the next Communications Act could revise this current system. 
Under the previous Coalition government, Jeremy Hunt, then Secretary of State for Culture, Media and Sport, set out in September 2011 his priorities for what would have been a Communications Bill in that Parliament, a bill which still has not materialised by August 2016. Acknowledging that prominence in the EPG was still an important "lever", Hunt stated: "we will need a lighter-touch model which, in particular, means that ministers and regulators will have to move away from micromanaging programme outcomes" (Hunt 2011). While it is unclear precisely what Hunt was referring to at this point, the originations quotas could easily be encompassed within this approach. If such thinking was applied by the current Secretary of State for Culture, Media and Sport and the wider government, quotas for first-run UK originations that apply to the commercial PSBs could come under pressure for liberalisation or removal. The critical political economy approach here draws an imperative for considering the politics of the media system in the UK. In this sense, a focus is required on and there is a need for analysis of the politics of media policy of the current Conservative government. It is one which has been shown to be one deeply entwined with the press interests (Freedman 2014, 1), and one strongly antipathetic to the BBC (especially seen during the tenure of the former Secretary of State for Culture, Media and Sport, John Whittingdale). While speculation may offer little, we might confidently state that were the public service television system to be liberalised in a future Communications Act, it would not come as a great surprise. The first throes of this can be seen in the manner which the future of $\mathrm{C} 4 \mathrm{C}$ has been handled by the government in recent years.

As well as the wider public service television system being up for debate and having the potential to be rearranged, it is also important to note the government had been considering various options for the future of $\mathrm{C} 4 \mathrm{C}$ (and with it the broadcast entity Channel 4 itself), with the option that it might be fully privatised by the government. This would mean that its ownership as well as its funding model would be sourced from solely within the private sector, and its status as a statutory corporation would end. It was in the context of this the House of Lords (UK Parliament) Select Committee on Communications released a report on the matter. The committee recommended the continuation of the current ownership model, ruling out both full and part-privatisation, or the alternative option of mutualisation (House of Lords, Select Committee on Communications 2016, 7). That said, John Whittingdale, argued in evidence to the Committee for at least a part role for the private sector in $\mathrm{C} 4 \mathrm{C}$, 
through commercial partnership or investment (House of Lords, Select Committee on Communications 2016, 17-18).

Later in May 2016 reports suggested that the privatisation of $\mathrm{C} 4 \mathrm{C}$ had been ruled out by the government, under a Prime Minister who was two months later replaced by Theresa May (Sweney 2016). However, until the present government or its successor gives full and unconditional support for $\mathrm{C} 4 \mathrm{C}$ to remain on its present statutory footing, it will remain as a potential target both for commercial investors and for the proponents of a UK broadcasting system which is nothing less than fully liberalised. It is possible that a privatised Channel 4 could fully retain its PSB remit, a point which Whittingdale considered in his evidence to be plausible, suggesting that for a buyer of $\mathrm{C} 4 \mathrm{C}$ it would be "the last thing they would want to do was to undermine it by moving downmarket or changing the nature of the programming" (House of Lords, Select Committee on Communications 2016, 17). That said, there is no particular reason why that would be the case, with the possibility that the government would receive a much higher sale price if it were freed from its public service obligations.

\section{Conclusion}

It has been argued in this article that the current public service television system functions both for the benefit of the audience and for the commercial PSBs: the audience has access to significant levels of original material other than sports programming, while the broadcasters have in place the basis of their financial models. A cutting back of the system would be in essence ideological given the successful financial functioning of the system as it currently stands, underpinned by the audience demand for the five main PSB channels. Moves to dismantle or diminish this system may have the unintended consequences of diminishing the financial success of the commercial PSBs, while weakening the overall size of the television market (with probable declines in investment). Specifically on the first-run originations, a weakening of those regulations could diminish quality in the sector, lead to additional acquisitions and re-runs on the most watched channels, while inadvertently reducing advertising revenues. The point being, the regulated broadcasting system which includes both more-regulated PSBs and less-regulated non-PSBs can be economically as well as culturally valuable. 
The use of the critical political economy approach allows the testing of the benefits and drawbacks of market-based broadcasters delivering a PSB remit. Such analysis draws attention to the strength of the current system, allowing for a strong evidencebased position from which to argue for a public service system based on mixedfunding models, which provides the audience with programming which is distinct from what the market would provide if it were left solely to its own devices. However, the current system is one which could yet be subject to change under the current Conservative government, as ideologically-driven detractors continue to exert pressure on the very concept of public service television. 
(1) The main analysis for this article was written in July and August 2015. When the broadcasters' spending on first-run UK originations is discussed below, the 2013 figures were the most recently available that were suitable for comparison. A previous version of this research was presented at the Capitalism, Culture and Media conference, University of Leeds, 7-8 September 2015. The core findings were submitted to the public inquiry, $A$ Future for Public Service Television: Content and Platforms in a Digital World, chaired by Lord Puttnam.

(2) The non-PSB category include the portfolio channels of these organisations (eg. ITV2); those channels originating in the UK (eg. Sky 1, BT Sport 1); and finally those channels originating outside of the UK but rebroadcast there (eg. RT [Russia Today]). As of August 2016 there were more than 1000 television channels licenced for broadcast in the UK (Ofcom 2016).

(3) For example, the ITV 'portfolio' (an Ofcom term) of channels on DTT is comprised of: ITV, ITV2, ITV Be, ITV 3, ITV 4, CITV. In Northern Ireland, the ITV licensee is UTV (formerly Ulster Television), which was bought in 2015 by ITV plc. STV in Scotland remains the only ITV franchise not to be owned by the company, which is rather owned by STV Group plc (which takes its name from 'Scottish Television'). The Channel 4 portfolio of channels is comprised of: Channel 4, More4, E4, 4Seven, 4Music and Film4. The Channel 5 portfolio of channels is comprised of: Channel 5, 5 STAR and 5 USA.

(4) Following the purchase of Channel 5 by Viacom, the individual profit breakdown for the company has not been made available.

(5) This option was taken, informed by a Putting Quality First (BBC 2010) proposal to impose a spending cap of 9 per cent on sports rights across a four-year period for non-listed sports events. While spending on sports rights and first-run UK originations in sports are not one and the same, it can be estimated that a high percentage of the spend goes on buying the rights. A 15 percent cut applied to $£ 261 \mathrm{~m}$ would suggest a sports rights budget of some $£ 221 \mathrm{~m}$. In this case, the BBC would be spending more than the 49.4 percent as used in this approximation. As a result, 16.49 per cent might even be too high a figure for the commercial PSBs, but within the context of this analysis, it can be used as a reliable approximation on which to base the argument. 


\section{References}

Atkinson, Paul, and Amanda Coffey. 2004. "Analysing documentary realities.” In Qualitative Research: Theory, Method and Practice, edited by David Silverman, 5675. Sage: London.

BBC. 2010. Putting Quality First: The BBC and Public Space. London: BBC.

BBC. 2015. BBC Annual Report and Accounts 2014/15. London: BBC.

BBC Trust. 2011. Delivering Quality First: October 2011. London: BBC Trust.

BBC Trust/MTM London. 2011. The BBC's processes for the management of sports rights. Review by MTM London Ltd presented to the BBC Trust's Finance and Compliance Committee, 13th January 2011. London: BBC Trust.

Born, Georgina. 2003. "Strategy, Positioning and Projection in Digital Television: Channel Four and the Commercialization of Public Service Broadcasting in the UK." Media, Culture \& Society 25 (6): 773-799.

Department for Culture, Media and Sport. 2016. "A BBC for the future: a broadcaster of distinction." Accessed June 7, 2016.

https://www.gov.uk/government/uploads/system/uploads/attachment_data/file/524863 / DCMS_A_BBC_for_the_future_linked_rev1.pdf.

Donders, Karen, and Van den Bulck, Hilde. 2016. "Decline and fall of public service media values in the international content acquisition market: An analysis of small public broadcasters acquiring BBC Worldwide content." European Journal of Communication 31 (3): 299-316.

Doyle, Gillian, and Vick, Douglas Wendell. 2003. "The Communications Act 2003: A New Regulatory Framework in the UK." Convergence 11 (3): 75-94.

Farey-Jones, Daniel. 2012. "Northern \& Shell to unveil $£ 40.2 \mathrm{~m}$ post-tax profit." Media Week, May 28. Accessed November 30, 2015

http://www.mediaweek.co.uk/article/1134130/northern---shell-unveil-402m-post-taxprofit

Forster, Nick. 1994. "The Analysis of Company Documentation.” In Qualitative Methods in Organizational Research: A Practical Guide, edited by Catherine Cassell, and Gillian Symon, 147-166. London: Sage.

Freedman, Des. 2014. The Contradictions of Media Power. London: Bloomsbury Academic.

Garnham, Nicholas. 1979. "Contribution to a political economy of masscommunication." Media, Culture \& Society 1: 123-146.

Garnham, Nicholas. 2010. "The Political Economy of Communication Revisited." In The Handbook of Political Economy of Communications, First Edition, edited by 
Janet Wasko, Graham Murdock, and Helena Sousa, 41-61. Oxford: Blackwell Publishing Ltd.

Golding, Peter, and Graham Murdock. 2000. "Culture, Communications and Political Economy." In Mass Media and Society, third edition, edited by James Curran, and Michael Gurevitch, 70-92. London: Arnold.

Hardy, Jonathan. 2012. "UK Television Policy and Regulation, 2000-10." Journal of British Cinema and Television 9 (4): 521-547.

Hardy, Jonathan. 2014. Critical Political Economy of the Media: an introduction. Abingdon: Routledge.

Hewlett, Steve. 2015. "Why BBC Worldwide must open its books to licence fee payers." The Guardian, November 15. Accessed November 17, 2015.

http://www.theguardian.com/media/media-blog/2015/nov/15/bbc-worldwide-licencefee-benefits-commercial?CMP=share_btn_tw.

House of Lords, Select Committee on Communications. 2016. A privatised future for Channel 4? (HL Paper 17, First Report of Session 2016-17). London: The Stationary Office Limited.

Hunt, Jeremy. 2011. "Boldness be my friend." Speech delivered at the RTS Cambridge Convention, September 14. Accessed September 2, 2015.

https://www.gov.uk/government/speeches/royal-television-society--2.

ITV. 2012. Delivering growth through Transformation. ITV plc Annual Report and Accounts for the year ended 31 December 2012. London: ITV plc.

ITV. 2014. ITV set for continued growth after another strong year. ITV plc Annual Report and Accounts for the year ended 31 December 2014. London: ITV plc.

Mason, Jennifer. 2002. Qualitative Researching, second edition. London: Sage.

McChesney, Robert. 2013. Digital Disconnect: how capitalism is turning the Internet against democracy. New York: The New Press.

Mosco, Vincent. 2009. The Political Economy of Communication, second edition. London: Sage.

Murdock, Graham, and Peter Golding. 1997. "For a Political Economy of Mass Communication." In The Political Economy of the Media, Volume One, edited by Peter Golding, Graham Murdock, 3-32. Cheltenham: Edward Elgar.

Murdock, Graham. 2010. Political Economies as Moral Economies: Commodities, Gifts, and Public Goods. In The Handbook of Political Economy of Communications, First Edition, edited by Janet Wasko, Graham Murdock, and Helena Sousa, 13-40. Oxford: Blackwell Publishing Ltd.

Northern \& Shell. 2013. "Northern \& Shell Media Group Limited. Group Annual 
Report \& Financial Statements. For The Year Ended 31 December 2013.” Accessed November 30, 2015. http://www.northernandshell.co.uk/wp-

content/uploads/2014/10/2013-Group-Annual-Report-Financial-Statements.pdf.

Ofcom. 2004. Ofcom review of public service television broadcasting: Phase 1 - Is television special? London: Ofcom.

Ofcom. 2013a. The Ofcom Broadcasting Code (incorporating the Cross-promotion Code). London: Ofcom.

Ofcom. 2013b. "PSB compliance reporting, 2013.” Accessed August 11, 2016. http://stakeholders.ofcom.org.uk/binaries/broadcast/reviews-investigations/psbreview/psb2013/compliance.pdf.

Ofcom. 2015a. The Communications Market Report. London: Ofcom.

Ofcom. 2015b. Public Service Broadcasting in the Internet Age: Ofcom's Third Review of Public Service Broadcasting. Statement. London: Ofcom.

Ofcom. 2015c. PSB Annual Report 2015. London: Ofcom.

Ofcom. 2015d. Public Service Broadcasting in the Internet Age: Ofcom's Third Review of Public Service Broadcasting. Data annex. London: Ofcom.

Ofcom. 2016. "Cable and Satellite Channels". Accessed August 11, 2016. http://www.ofcom.org.uk/static/radiolicensing/html/tv/cs/cabandsat-main.htm.

Potschka, Christian. 2012. Towards a Market in Broadcasting: Communications Policy in the UK and Germany. Basingstoke: Palgrave Macmillan.

S4C. 2015. "Introducing S4C.” Accessed September 1, 2015. http://www.s4c.cymru/abouts4c/corporate/e_index.shtml.

Sweney, Mark. 2016. "Government drops full Channel 4 privatisation - but may sell off stake". The Guardian, May 10. Accessed 11 August, 2016.

https://www.theguardian.com/media/2016/may/10/government-channel-4privatisation-stake-nao.

Thompson, Peter. 2011. "Neoliberalism and the political economies of public television policy in New Zealand." Australian Journal of Communication 38(3): 116.

Viacom. 2014. "Form 10-K Annual Report. Filed Nov 13, 2014." Accessed November 20, 2015. http://ir.viacom.com/secfiling.cfm?filingID=1339947-14$50 \& \mathrm{CIK}=1339947$. 